có 82 trường hợp tắc hoàn toàn và 24 trường hợp hẹp trên $70 \%$ trên hình ảnh chụp động mạch vành. Hầu hết bênh nhân chỉ tổn thương 1 nhánh chiếm $64,2 \%$ nhưng cũng có đến $10,4 \%$ bênh nhân có tổn thương 3 thân động mạch vành. Những bệnh nhân tổn thương 3 thân động mạch vành thường có tiền sử đau thắt ngực trước đó và có nhiều yếu tố nguy cơ kèm theo. Theo tác giả Huỳnh Kim Phượng thì $71,1 \%$ có hẹp nhánh liên thất trước động mạch vành trái, $53,1 \%$ có hẹp nhánh mũ và $56,2 \%$ có hẹp động mạch vành phải khi nghiên cứu ở bệnh nhân đái tháo đường type 2 [4]. Kết quả của chúng tôi phù hợp với nghiên cứu của Nguyễn Văn Tần cũng cho thấy tỷ lệ động mạch vành phải là 43,1\%[3] và Trần Hòa là đọng mach liên thất trước $47 \%$, động mạch vành phải $43 \%$ và động mạch mũ $10 \%$ [7].

\section{KẾT LUÂN}

Đa số gặp lứa tuổi > 60 tuổi chiếm tỷ lệ $78,3 \%$. Gần như các bệnh nhân đều có yếu tổ nguy cơ, đặc biệt là THA và rối loạn lipid máu. Tất cả bệnh nhân khởi phát với triệu chứng đau ngực, trong đó 78,3 \% là đau ngực điển hình. Vị trí tổn thương các nhánh động mạch vành đều gặp đặc biệt tổn thương 1 nhánh chiếm 64,2\% nhưng cũng có đến $10,3 \%$ bệnh nhân có tổn thương 3 thân động mạch vành.

\section{TÀI LIÊU THAM KHẢO}

1. Jayaraj J.C., Davatyan K., Subramanian S.S., et al (2018). Epidemiology of Myocardial Infarction. Myocard Infarct.

2. Sanchis-Gomar F., Perez-Quilis $C_{\text {., Leischik }}$ R., et al (2016). Epidemiology of coronary heart disease and acute coronary syndrome. Ann Transl Med 2016;4(13):256.

3. Nguyễn Văn Tân, Châu Văn Vinh (2019). Nghiên cứu đăc điểm tổn thương đông mach vành ở bệnh nhân cao tuổi nhồi máu cơ tin cấp thất phải. Tap chí y hoc TP. Hồ Chí Minh, 23(2):176 - 181.

4. Huỳnh Kím Phượng, Trương Thành Viễn (2016). Đặc điểm lẩm sàng và cận lâm sàng bệnh nhân tữ 45 tuổi trở lên bi nhồi máu cơ tim cấp kèm đái tháo đường type 2 (2016). Tạp chí y học TP. Hồ Chí Minh, 20(2):220-233.

5. Nguyê̂n Thị Thanh Trung (2014). Nghiên cứu đặc điểm lâm sàng và cận lâm sàng, kết quả điêu trị nhồi máu cơ tim cấp có ST chênh lên tại bệnh việ đa khoa Thái Bình. Y học thực hành (905). Số 2/2014, tr 16-19.

6. Lê Cao Phương Duy (2019). Hiệu quả sớm của thủ thuật hút huyết khối trong can thiêp mach vành qua da thì đâu ở bênh nhân nhồi máu cơ tim cấp có ST chênh lên. Tạp chí y học TP. Hồ Chí Minh, 23(6):83-90.

7. Trân Hòa, Vũ Văn Hoàng, Nguyễn Hữu Khoa Nguyên, Trương Quang Bình (2012). Kết quả can thiệp động mạch vành tiên phát (thì đâu) trong điều trị nhồi máu cơ tim cấp có ST chênh lên tai Bênh viên Y Dước TP Hồ Chí Minh.Tap chí Y Học Thành Phố Hồ Chí Minh, 16(1):94-100.

\title{
GIST ĐAI TRÀNG Ở TRẺ EM: BÁO CÁO CA BỆNH VÀ TỔNG QUAN Y VĂN
}

\section{TÓM TẮT}

Mục đích: Báo cáo ca bệnh hiếm gặp u mô đệm ông tiểu hoá (GIST) của đại tràng ở tré em. Phướng pháp: Báo cáo ca bệnh và tổng quan y văn. Kết quả: Bệnh nhân (BN) nữ 13 tuổi vào viện vì đau bụng cơn, nổn, đai tiên phân máu. Siêu âm ổ bung phát hiên khối lồng ruột đại- đại tràng, vị trí hạ sườn trái, kích thước 54 x 43 x 51mm. Cắt lớp vi tính thây khối lồng với tổ chức nghi u đại tràng xuống. Nội soi đại tràng thấy u đại tràng xuống kích thước 40 x $30 \mathrm{~mm}$, có hoai tử trung tâm. BN được phẫu thuật nội soi cấp cứu tháo lồng ruột. Sau phẩu thuật 1 ngày BiN bi lồng ruột

*Bênh viên Đa khoa Saint Paul

Chịu trách nhiệm chính: Nguyễn Thị Hồng Vân

Email: hongvanyd@gmail.com

Ngày nhân bài: 14.4.2021

Ngày phản biên khoa họ: 26.5.2021

Ngày duyệt bài: 15.6.2021
Nguyễn Thị Hồng Vân*, Lương Anh Quân, Trẩn Văn Quyết*; Trần Ngọc Sơn*

tái phát với các triệu chứng tắc ruột, được phẫu thuât cấp cứu cắt đoạn đại tràng trái với mép cắt cách khối u $3-5 \mathrm{~cm}$. Kết quả giải phẫu bênh là u GIST và diên cắt vi thể không có tế bào u. Sau mổ bệnh nhân hồi phục tốt, ra viện sau mổ 7 ngày. Theo dổi 3 năm không có biến chứng và không thây u tái phát hay di că̆n. Kết luân: U GIST đại tràng hiếm găp ở trẻ em. Phẫu thuất triệt căn cắt đoạn đại tràng với mép cắt trên và dưới âm tính là phướng pháp điêu trị hiệu quả trong bệnh lý này trong giai đoạn u tại chỗ.

Tư khoá: U GIST trẻ em, đại tràng.

\section{SUMMARY}

\section{COLONIC GIST IN CHILDREN: A CASE}

REPORT AND LITERATURE REVIEW

Aim: Report a rare case of colonic GIST in a treatment child. Method: A case report and literature review. Result: A 13 years old girl was admitted to our center for abdominal pain, bilious vomiting and hematochezia. Abdomainal ultrasound showed a 
colon- colonic intussusception in the left lower quatdrant, $54 \times 43 \times 51 \mathrm{~mm}$ in size. Computed tomography showed an intussuception with a lesion suspected for a left colonic tumor. Colonic endoscopy showed a decending colonic tumor with $40 \times 30 \mathrm{~mm}$ in diameter with central necrosis. The patient underwent emergent laparoscopic reduction for the intussusception. On the first postoperative day, the patient suffered from recurrent intussusception with consequent intestinal obstruction. Segmental left colectomy was performed with the tumor margins 3-5 $\mathrm{cm}$. The result of pathology showed GIST with microscopic free margins. The patient recovered well and was discharged on post operative day 7. At a follow up of 3 years, the patient had no complication, recurrence or metastasis. Conclusion: Colonic GIST is rare in children. Segmental colonic resection with negative margins can be curative for localized GIST.

Key words: Pediatric GIST, Colonic

\section{I. ĐĂT VẤN ĐỀ}

U mô đệm đường tiêu hóa hay còn gọi là GIST (Gastrointestinal Stroma Tumor) là loại u có nguồn gốc từ trung mô đường tiêu hóa, GIST chiếm từ 0,1 đến $3 \%$ các trường hợp u đường tiêu hóa, thường gặp ở bệnh nhân tuổi trung niên hoặc tuổi già, được mô tả đầu tiên bởi Mazur và Clark năm $1983^{1}$. Bệnh rất hiếm gặp ở trẻ em vì thường không được chẩn đoán hoăc chẩn đoán nhầm với các bệnh lý ổ bụng khác. Một nghiên cứu được đăng tải trên Lancet năm 2013 cho thây tỷ lệ gặp GIST ở trẻ dưới 20 tuổi là 0,02 trên 1 triệu trẻ mỗi năm, hay $0.4 \%$ trong tất cả các trường hợp GIST ${ }^{2}$. Đa phần GIST xảy ra ở dạ dày, rât ít gặp ở các vị trí khác như ruột non, đại tràng, thực quản hay ngoài đường tiêu hoá. Trên thế giới, chỉ có một vài ca bệnh GIST đại tràng ở trẻ em được báo cáo riêng lẻ ${ }^{3}$. Tại Việt Nam, tác giả TH Sớn đã thông báo một số trường hợp GIST ở người lớn được điều trị bằng phẫu thuật và dùng thuốc điều trị đích Imatinib (Gleevec) để điều trị GIST ở các vị trí dạ dày, ruột non và trực tràng ${ }^{4}$. Theo tìm hiểu của chúng tôi, cho tới nay tại Việt Nam chưa có nghiên cứu nào về GIST đại tràng ở trẻ em được báo cáo. Sự thống nhất trong phác đồ chẩn đoán và điều trị GIST ở người lớn đã được đồng thuận theo hiêp hội ung thư quốc tế NCCCN. Tuy nhiên với sự hiểm gặp và bản chất sinh học khác biệt của GIST trẻ em, cũng như các hình thái lâm sàng đa dạng, các phương pháp điều trị còn nhiều tranh cãi, việc chẩn đoán và điều trị GIST ở trẻ em còn nhiều khó khăn. Chúng tôi báo cáo môt trường hợp bệnh nhi GIST đại tràng được chẩn đoán và phẫu thuật thành công.

\section{BÁO CÁO CA BệNH}

Bệnh nhân nữ, 13 tuổi, tiền sử khoẻ mạnh, vào viện vì đau bụng cơn vùng hạ sườn trái kèm theo nôn dịch xanh, đại tiện phân máu cách vào viện 1 ngày. Khám khi vào viện: trẻ tỉnh, da niểm mạc hồng, sốt 38 độ $C$, huyết động ổn, bụng mềm, không chướng, ấn đau hạ sườn trái, không có phản ứng thành bụng, khồng có cảm ứng phúc mạc, không sờ thấy khối lồng, thăm trực tràng thấy phân lẫn máu đỏ tươi. Siêu âm ô bụng có hình ảnh khối lồng đại tràng vùng hạ sườn trái đường kính $54 \times 43 \mathrm{~mm}$, trên đoạn dài $51 \mathrm{~mm}$, bên trong có khối giảm âm kích thước $40 \times 30 \mathrm{~mm}$, có tín hiệu mach trên siêu âm Doppler (Hình 1). Chụp cắt lớp vi tính ổ bụng thấy hình ảnh khối lồng đại tràng xuống đường kính $35 \mathrm{~mm}$, trên đoạn dài $74 \mathrm{~mm}$, thành mỏng, ngấm thuốc bình thường sau tiêm, bên trong có khối tỷ trọng tổ chức, bờ đều, ranh giới rõ, sau tiêm ngấm thuốc mạnh, không đồng nhất, kích thước $22 \times 36$ mm, không thây thâm nhiếm mõ và hạch to lân cận. Nội soi đại tràng thấy đại tràng xuống gần góc lách có khối u kích thước khoảng $40 \times 30 \mathrm{~mm}$, choán gần hết lòng đại tràng, đầu khối hoại tử có giả mạc (Hình 2). Các xét nghiệm hình ảnh trước mổ đều hướng tới GIST đại tràng. Các xét nghiệm khác trong giới hạn bình thường.

Bệnh nhân được chẩn đoán lồng ruột cấp do u đại tràng và được phẫu thuật nội soi, trong mổ thây lồng ruột đại- đại tràng vị trí đại tràng trái, sau tháo ruột nề nhẹ, không có điểm hoại tử, khối u ở vị trí đại tràng góc lách, không đẩy lồi hay xâm lấn ra ngoài thanh mạc, không thủng. Do chưa chuẩn bị đại tràng sạch nên chúng tôi chỉ mổ cấp cứu tháo khối lî̀ng. Tuy nhiên, sau mổ 1 ngày, BN xuất hiện đau bụng cơn, tăng dần, nôn dịch vàng, bụng ấn đau hạ vị, chụp Xquang bụng có hình ảnh mức nước - hới. BN được chẩn đoán tắc ruột do u đại tràng trái và được mổ cấp cứu. Chúng tôi mổ mở đường dưới sườn trái, trong mổ thấy các quai ruột non, đại tràng lên, đại tràng ngang giãn tới vị trí chuyển tiếp ở đại tràng góc lách, nguyên nhân là do khối u đại tràng góc lách kích thước $3,5 \times 3 \mathrm{~cm}$ gây tắc lòng đại tràng (Hình 3 ), ổ bung đại thể không thây có di căn. BN được cắt đoạn đại tràng trái có $u$, nối tận - tận, diện cắt trên cách rìa khối u $5 \mathrm{~cm}$, diên cắt dưới cách u $3 \mathrm{~cm}$. Giải phẫu bệnh sau mổ: U tế bào hình thoi (GIST), diện cắt trên và dưới không có tế bào u. Sau mổ bệnh nhân hồi phục tốt, ra viện sau mổ 7 ngày. BN tái khám định kỳ sau 3 tháng, 6 tháng và mối 6 tháng trong 3 năm liên tiếp sau mổ không có biến chứng tắc ruột, không thấy dấu hiệu u tái phát hay di căn. 


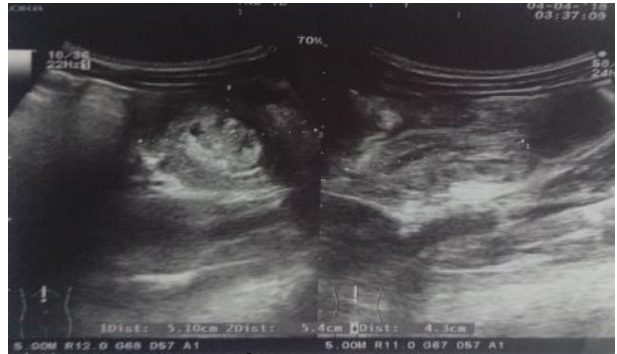

Hinh 1: Siêu âm ổ bụng có hình ảnh khôi lồng đại tràng, trong có khối giảm âm, có tín hiệu mạch trên siêu âm Doppler

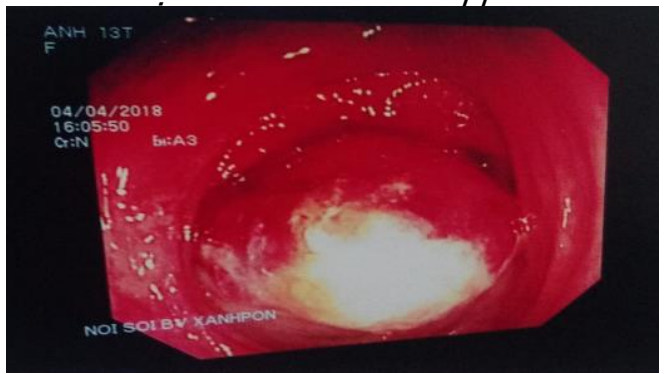

Hinh 2: Soi đại tràng có khối giống polyp đại tràng vi trí góc lách kích thước khoảng 40×30 mm, choán gần hêt lòng đại tràng, đầu khôi hoại tư có giả mạc

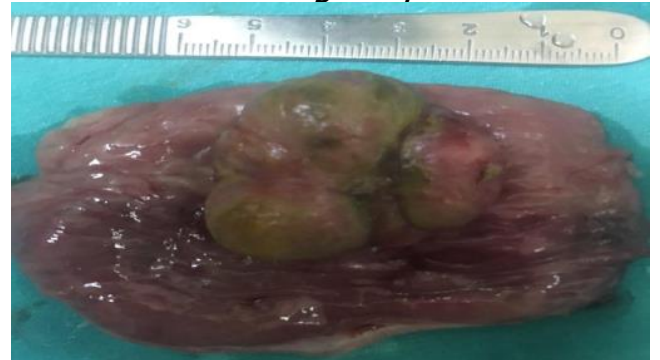

Hình 3: Hình ảnh trong mổ khôi u đại tràng góc lách

\section{BÀN LUÂN}

U mô đệm đường tiêu hóa hay còn gọi là GIST (Gastrointestinal Stroma Tumor) là loại u trung mô (mesenchymal tumor) bắt nguồn từ tế bào Cajal (interstial cells of Cajal). GIST chiếm từ 0,1 đến $3 \%$ các trường hợp u đường tiêu hóa, rất hiếm gặp ở trẻ em với tỷ lệ thay đổi tùy theo từng báo cáo từ $0,4 \%$ đến $2,7 \%$ các trường hợp GIST ${ }^{2,5}$. Trong khi người lớn thường phát hiện bệnh sau tuổi 60, đa số GIST ở trẻ em gặp từ 10-18 tuổi, độ tuổi trung bình là 13 tuổi. Bệnh rất hiếm gặp ở trẻ dưới 5 tuổi, tuy nhiên đã có một vài trường hợp đã được báo cáo ở trẻ nhỏ và trẻ sơ sinh ${ }^{3}$. Trên thực tế, tỷ lệ GIST ở trẻ em vẫn chưa được thống kê đây đủ vì tính chất hiếm gắp và thường chẩn đoán nhâm với các bệnh lý bụng cấp tính và mạn tính khác. Khác với người lớn, GIST ở trẻ nữ thường gặp hơn trẻ nam với tỷ lệ khoảng 70\%. GIST có thể gặp ở tất cả các vị trí của ống tiêu hóa nhưng chưa có nghiên cứu nào đủ lớn về vị trí thường gặp của GIST trẻ em. Theo nghiên cứu tổng hợp về u GIST ở trẻ em của Martin Benesch và cộng sự năm 2009, có 49 trường hợp u GIST ở dạ dày, tiếp theo là ruột non (10 ca), 7 trường hợp ở đại trực tràng, 3 trường hợp ở vị trí khác (mạc nối, thành bụng $)^{6}$. Kích thước khối u thay đổi từ 1,5 tới $35 \mathrm{~cm}$ (trung bình 5,7cm). Vài bệnh nhân có nhiều khối u hoặc có các nhân vệ tinh xung quanh. Những khối u lớn thường bị thiếu máu trung tâm gây ra hiện tượng hoại tử, loét trung tâm khối u gây ra tình trạng xuất huyết cấp tính hoặc mạn tính đường tiêu hoá. Đây cũng là triệu chứng hay gặp nhất ở GIST trẻ em chiếm 33,1\% các trường hợp, có thể kèm các triệu chứng tiêu hóa khác như đau bụng (19\%), sờ thây khối ở bụng $(7 \%)$, nôn, chán ăn, gây sút cân (4\%), thiếu máu². Môtt số trường hợp diễn biến âm thầm, khi phát hiện bệnh đã có di căn, vị trí di căn thường gặp nhất là gan, hạch bạch huyết và phúc mạc. Trường hợp của chúng tôi là bệnh nhân nữ, trong độ tuổi thường gặp của GIST trẻ em, BN cũng có biểu hiện xuất huyết tiêu hoá cấp tính nhưng là xuất huyết tiêu hoá thấp, kèm theo biểu hiện lồng ruột, tắc ruột thấp do khối u ở đại tràng trái mà không phải vị trí thường gặp ở dạ dày như các trường hợp khác. Các trường hợp lâm sàng GIST ở trẻ em với biểu hiện lông ruột, tắc ruột cũng đã được báo cáo trước đây với các vị trí u ở ruột non và đại tràng ${ }^{3}$.

GIST ở trẻ em được chia ra làm 4 loại. Loại thứ nhất phổ biến hơn cả, thường xảy ra ở trẻ trong độ tuổi 6-18 tuổi với biểu hiện khối u bụng, hầu hết xuất phát từ dạ dày. Loại thứ hai, được mô tả lần đâu năm 1997, với tên gọi là tam chứng Carney (bệnh nhân có bất kỳ hai trong ba bệnh lý sau GIST, u sụn phổi và u cận hạch vỏ thượng thận), bệnh không di truyền. Tới năm 2002, một loại khác được mô tả dựa trên tam chứng Carney, đó là hội chứng Carney- Stratakis với các biểu hiện tương tự tam chứng Carney nhưng được di truyền, có tính chất gia đình, thường xảy ra ở lứa tuổi 9- 46 tuổi. Loại cuối cùng là nhóm GIST bẩm sinh hay GIST sơ sinh, thường cân phẫu thuật cấp cứu sớm. Bệnh gặp ở trẻ trai và gái như nhau và thường gặp ở vị trí ruột non và đại tràng nhiêu hơn da dày ${ }^{3}$. BN của chúng tôi biểu hiện lâm sàng với khối u GIST đại tràng đơn độc, không có biểu hiện u sụn phổi hay u thượng thận, cũng không có các yếu tố di truyên về bênh. Do đó BN thuộc loai 1, loại phổ biến nhất ở trẻ em, tuy nhiên vị trí gặp ở đại 
tràng rất hiếm gặp.

Chẩn đoán GIST ở trẻ hiện nay còn nhiều khó khăn do triệu chứng lâm sàng đa dạng, không đặc hiệu, bển cạnh đó, bệnh rất hiếm gặp ở trẻ em nên ít được nghĩ đến trên thực tế lâm sàng. Do đó, chẩn đoán hình ảnh đóng vai trò quan trọng trong chẩn đoán, phát hiện di căn di căn, mối liên quan về mặt giải phẫu của u với các thành phần xung quanh. Chụp cắt lớp vi tính được là phương tiện phổ biến trong chẩn đoán và theo dõi GIST vì độ nhạy cao $(95 \%)$ và có khả năng đánh giá giai đoạn u 7 . Đặc điểm của GIST trên phim CT phụ thuộc vào kích thước và sự phát triển của khối u: Với khối u lớn $(>5 \mathrm{~cm})$, tổn thương thường phát triển ra bên ngoài, tăng sinh mạch, tỷ trọng không đồng nhất trên phim chụp có tiêm thuốc cản quang và thường có di căn; với những khối u nhỏ $(<5 \mathrm{~cm})$, tổn thương thường nằm ở dưới niêm mạc hoặc polyp đường tiêu hóa, tỷ trọng đồng nhất 7 . Hình ảnh tỷ trọng không đồng nhất quan sát được trên $\mathrm{CT}$ có thể là do hoại tử, thoái hóa hoặc chảy máu, hiếm khi gặp vôi hóa trong u. MRI cho kết quả tương tự CT và bệnh nhân không chịu ảnh hưởng của phóng xạ, tuy nhiên đây là phương pháp với thời gian chụp kéo dài, đòi hỏi phải gây mê trong quá trình chụp ở trẻ em, do đó ít được áp dụng trong các trường hợp cấp cứu. Nội soi tiêu hoá: Tổn thương GIST sẽ có xu hưởng xuất hiên dưới dạng một khối dưới niêm mạc, nhẵn đẩy lồi của niêm mạc bên trên, đôi khi kèm theo hoại tử hoặc xuất huyết. Sử dụng đồng thời siêu âm nội soi (EUS) cho phép phân biêt giữa và các tổn thương trong thành ruột và bên ngoài thành ruột, đồng thời có thể hướng dẫn sinh thiết 2. Bệnh nhân của chúng tôi đã được làm các xét nghiệm siêu âm ổ bụng, CT ổ bụng và nội soi đại tràng, cho thấy hình ảnh học điển hình của GIST.

Về điều trị, cho đến nay, phẫu thuật là phương pháp điều trị tiêu chuẩn cho những bệnh nhân GIST chưa có di căn. Mục tiêu của phẫu thuật là cắt bỏ hoàn toàn khối u tới mức âm tính diện cắt về mặt vi thể2,6,8. Phẫu thuật cắt khối u đơn thuân không được khuyến cáo vì tỷ lệ tái phát tại chỗ cao. Cắt đoạn đại tràng, cắt đoạn ruột hoặc cắt dạ dày hình chêm với mép cắt âm tính được áp dụng với các trường hợp khối u có kích thước nhỏ $2-5 \mathrm{~cm}$. Với các khối u lớn hơn $5-10 \mathrm{~cm}$ cần các phẫu thuật cắt rộng rãi hơn để đảm bảo triệt căn và tránh tái phát, như cắt đại tràng theo giải phẫu, cắt dạ dày bán phần hay toàn bộ $2,3,6$. Mặc dù tỳ lệ xâm lấn hạch lympho cao hơn ở người lớn, tuy nhiên việc nao vét hach không được thực hiện một cách thường quy. Chỉ nạo vét hạch trong các trường hợp có hach di căn nghi ngờ trước mổ hoặc trong mổ. Việc cắt bỏ khối di căn gan cũng được thực hiện ngay một thì khi có phát hiện trong mổ, các phương pháp được thực hiện như cắt gan hình chêm, cắt gan bán phần hay cắt gan không điển hình tuỳ từng trường hợp ${ }^{6}$. Về việc điều trị hoá chất imatinib và sunitinib cho GIST trẻ em chưa có nhiều trường hợp thống kê, tuy nhiên phương pháp này chỉ được áp dụng với các khối u lan rộng, kích thước lớn không thể phẫu thuật triệt căn RO được hoặc khi đã có di căn hoặc tái phát ${ }^{3,6}$.

BN trong báo cáo này ở phẫu thuật lần đầu do tình trạng lồng ruột cấp tính, BN chưa được chuẩn bị đại tràng trước đó, nên phẫu thuật viển chỉ phẫu thuật nội soi tháo khối lồng, dự kiến chuẩn bị sạch đại tràng sẽ phẫu thuật cắt đại tràng thì sau. Tuy nhiên sau 1 ngày BN lồng ruột tái phát và tắc ruột hoàn toàn đòi hỏi phẫu thuật cấp cứu. Phẫu thuật viên đã quyết định cắt đoạn đại tràng với mép cắt cách khối u $3-5 \mathrm{~cm}$. Mặc dù trong tình trạng tắc ruột, $\mathrm{BN}$ được nối ruột ngay tận tận. BN hồi phục tốt, không có biến chứng trong và sau mổ. Sau đó $B N$ không dùng hoá chất bổ trợ vì khối u nhỏ, diện cắt âm tính và không phát hiện di căn. Kinh nghiệm này cho thấy có thể lựa chọn cắt đoạn đại tràng trái và nối ngay thì đầu trong trường hợp cấp cứu GIST gây tắc ruột ở trẻ em mà không nhất thiết phải chuẩn bị sạch đại tràng trước đó. BN của chúng tôi được theo dõi định kì sau mổ 3 năm không có biến chứng tắc ruột, không có dấu hiệu tái phát tại chỗ hay di căn. Điều này cho thấy ở trẻ em phương pháp phẫu thuật cắt đoạn đại tràng (với đảm bảo mép cắt âm tính) thay cho cắt nửa đại tràng có thể đem lại kết quả tốt. Ở trẻ em, các phẫu thuật bảo tồn tối đa giải phẫu sẽ có ưu điểm cho phát triển sau này của trẻ. Mặc dù hâu hết các trường hợp GIST ở trẻ em được chữa khỏi nhờ phẫu thuật triệt căn, tuy nhiên một số trường hợp theo dõ̉i lâu dài có ghi nhận tái phát sau nhiêu năm (2 BN có tam chứng Carney, tái phát sau lần lượt 22 và 29 năm $)^{6}$. Do đó $B N$ cần được theo dõi lâu dài sau điều trị để phát hiện sớm tái phát và di căn xa.

\section{KẾT LUẬN}

GIST ở trẻ em là loại u trung mô đường tiêu hóa rất hiếm gặp, vị trí ở đại tràng lại càng hiếm gặp hơn. Đây là thông báo lâm sàng đầu tiên tại Việt Nam về GIST đại tràng ở trẻ em. Trên lâm sàng, GIST đại tràng có thể dẫn đến các tình trạng cấp tính như lồng ruột, tắc ruột, đại tiện phân máu. Việc phẫu thuật cắt đoạn đại tràng 
mép cắt trên và dưới âm tính, nối ngay thì đầu với GIST đại tràng kích thước nhỏ, giai đoạn tại chỗ trong tình trạng cấp cứu là có thể thực hiện được và đem lại kết quả bước đầu tốt.

\section{TÀI LIÊU THAM KHẢO}

1. Michael T. Mazur, M.D, H. Brent Clark, M.D, Ph.D. Gastric stromal tumors: Reappraisal of histogenesis. The American Journal of Surgical Pathology. 1983; 7(6): 507-519.

2. Quiroz HJ, Willobee BA, Sussman MS, et al. Pediatric gastrointestinal stromal tumors-a review of diagnostic modalities. Transl Gastroenterol Hepatol. 2018; 3: 54

3. Kotb $M$, Abdelaziz M, Beyaly M, Mekawy $M$, Rashwan H, Mashali N. Neonatal Gastrointestinal Stromal Tumor of the Sigmoid Colon: A Case Report and Review of Literature. Fetal and Pediatric Pathology. 2020; 39(2): 172-178.
4. Trịnh Hồng Sơn. GIST trực tràng kích thước lớn. Tuyển Tập Các Bài Viết Thổng Báo Lâm Sàng. Nhà xuất bản Y hoc; 2014.

5. Kaemmer DA, Otto J, Lassay L, Junge $K_{\text {, }}$ Klinge U. The Gist of Literature on Pediatric GIST. J Pediatr Hematol Oncol. 2009; 31(2): 108-112.

6. Benesch M, Wardelmann E, Ferrari A, Brennan B, Verschuur A. Gastrointestinal stromal tumors (GIST) in children and adolescents: A comprehensive review of the current literature: Gastrointestinal Stromal Tumors. Pediatr Blood Cancer. 2009; 53(7):1171-1179.

7. Herzberg M, Beer $M$, Anupindi S, Vollert $K$ Kröncke T. Imaging pediatric gastrointestinal stromal tumor (GIST). Journal of Pediatric Surgery. 2018; 53(9):1862-1870.

8. Falcone ME. Pediatric Gastrointestinal Tumors Journal of Diagnostic Medical Sonography. 28(3): 131-134.

\section{HIỆU QUẢ BỔ SUNG SỮA NƯớC HANIE KID LÊN TÌNH TRANG DINH DƯỡNG, SỨC KHỎE VÀ KHẢ NĂNG CHẤP NHẬN SẢN PHẨM CỦA HỌC SINH LỚP MộT}

\begin{abstract}
TÓM TẮT.
Nghiên cứu có đối chứng, ngẫu nhiên cụm nhằm đánh giá hiệu quả bổ sung Sản phẩm dinh dưỡng sữa pha sắn Hanie Kid dạng lỏng lên tình trạng dinh dưỡng, sức khỏe và khả năng chấp nhận sản phẩm đối với học sinh lớp một (6-7 tuổi). Nghiên cứu được hoàn thành tại Thái Bình vào tháng 3/2021 với 55 trẻ nhóm can thiệp bổ sung Sữa nước Hanie Kid 2 lần/ngày trong 2 tháng và 55 trẻ nhóm chứng với chế độ ăn thông thường. Kết quả nghiên cứu cho thây bổ sung Sữa nước Hanie Kid đã có tác động tích cực: cân nặng trung bình tăng $0,57 \mathrm{~kg}(0,93 \pm 0,3 \mathrm{~kg}$ so với $0,36 \pm 0,17 \mathrm{~kg} ; \mathrm{p}<0,01)$; chiêu cao trung bình tăng $0,37 \mathrm{~cm}(0,96 \pm 0,10 \mathrm{~cm}$ so với $0,59 \pm 0,17 \mathrm{~cm}$; $\mathrm{p}<0,05)$; SDD thể nhẹ cân giảm 12,7\%; nguy cơ SDD nhẹ cân giảm $14,5 \%$ có ý nghĩa thống kê $(p<0,05)$. Có xu hướng cải thiện tình trạng nhiễm khuân hô hấp, tiêu chảy, táo bón, biếng ăn, khó ngủ, nhưng số lượng nhỏ, không có ý nghĩa thống kê ( $p>0,05)$.
\end{abstract}

Tư khóa: đa vi chất, sữa bổ sung, trẻ tiểu học, chiều cao, cân nặng.

\footnotetext{
${ }^{1}$ Trường Đại học Y Hà Nội

${ }^{2}$ Trường Đại học Y Dược Thái Binh

${ }^{3}$ Trường Cao đẳng Y tế Hà Tình

${ }^{4}$ Viện Dinh dưỡng Quốc gia

Chịu trách nhiệm chính: Phạm Quốc Hùng

Email: phamquochung@hmu.edu.vn

Ngày nhận bài: 9.4.2021

Ngày phản biên khoa hoc: 21.5.2021

Ngày duyệt bài: 11.6.2021
}

Phạm Quốc Hùng1, Trần Đình Thoan²,
Nguyễn Văn ${ }^{3}$, Trần Thúy $\mathrm{Nga}^{4}$

\section{SUMMARY}

EFFECTS OF HANIE KID MILK SUPPLEMENT ON NUTRITION STATUS, HEALTH, AND PRODUCT ACCEPTABILITY OF GRADE ONE STUDENTS

A cluster randomized and controlled study was conducted to evaluate the supplemental effects of Hanie Kid liquid powdered milk nutrition product on nutritional status, health and product acceptability for first graders (6-7 years old). The study was completed in Thai Binh in March 2021 with 55 infants supplemented with Hanie Kid Liquid Milk 2 times/day for 2 months and 55 control children using regular diet. Research results showed that Hanie Kid liquid milk supplementation had positive effects: average weight increased $0.53 \mathrm{~kg}(0.93 \pm 0.3 \mathrm{~kg}$ vs. $0.36 \pm$ $0.17 \mathrm{~kg} ; \mathrm{p}<0,01)$; average height increased $0.37 \mathrm{~cm}$ $(0.96 \pm 0.10 \mathrm{~cm}$ vs. $0.59 \pm 0.17 \mathrm{~cm} ; \mathrm{p}<0.05)$; underweight decreased $12.7 \%$; risk of malnutrition $14.5 \%$ weight loss with statistically significant $(p<0.05)$. Tendly improve respiratory infections, diarrhea, constipation, anorexia, difficulty sleeping, but but small quantity and not statistically significant ( $p>0.05)$.

Keywords: micronutrients, formula milk, primary school student, height, weight

\section{I. ĐĂT VẤN ĐỀ}

Tình trạng suy dinh dưỡng (SDD) nhẹ cân, thấp còi của trẻ em, đặc biệt là vùng nông thôn Việt Nam còn là vấn đề sức khỏe quốc gia ảnh hưởng đến tầm vóc, chiều cao, trí tuê và sức lao động của người Việt và được ngành y tế và 